\title{
Teaching basic digital competences for citizenship supported by learning platforms: the e-IRIS project
}

\author{
Catalina Guerrero-Romera \\ Department of Theory and History of \\ Education \\ University of Murcia \\ Murcia, Spain \\ cgromera@um.es

José Antonio Merlo-Vega
Department of Librarianship and
Information Studies
University of Salamanca
Salamanca, Spain
merlo@usal.es

\author{
Dora Sales-Salvador \\ Department of Translation and \\ Communication. \\ Universitat Jaume I \\ Castellón, Spain \\ dsales@uji.es
}

Miguel-Angel Vera-Baceta

Department of Research and

Innovation F- CEPAIM

Foundation CEPAIM

Murcia, Spain

mikel@cepaim.org

Alfonso Infante-Moro

Department of Financial Economics, Accounting and Operations

Management, University of Huelva

Huelva, Spain

alfonso.infante@decd.uhu.es

\author{
Jose Antonio Gómez-Hernández \\ Department of Librarianship and \\ Information Studies \\ University of Murcia \\ Murcia, Spain \\ jgomez@um.es
}
Aurora Cuevas-Cerveró
Department of Librarianship and
Information Studies
Complutense University
Madrid, Spain
macuevas@ucm.es

\begin{abstract}
The national digital skills plan approved by the Spanish government (2021) aims to train fifteen million people without basic skills for the environment created by technologies in all dimensions of life. To this end, it is funding one of its lines of action with almost 800 million euros and proposes, among other measures, a national network of digital training centres. The e-IRIS project has been designed to enable the digital inclusion sought by the Plan, based on an initiative of a group of universities, third sector foundations and companies. Therefore, the aim of this paper will be to describe the foundations of the e-IRIS project, the training actions and social innovation and participation actions designed, and the teaching-learning model proposed for its implementation, supported by a learning platform created specifically for the project. Taking the European Digital Competences Framework DIGCOMP[1] as a reference, and the Spanish public libraries as a learning framework, a training proposal has been designed that covers both the instrumental competences and those related to the critical and empowering use of digital tools, and a learning platform has been designed for its teaching and learning, and will be its benchmark. Depending on the degree of autonomy of the trainees, it will allow their initial assessment -with or without the support of face-to-face and online tutors-, the completion of activities according to different training itineraries, the obtaining of accreditations and the evaluation of results for the justification of the project. The project combines face-to-face training -for the purposes of social inclusion, citizen participation and attention to vulnerable groups on which it will focus- with the use of the e-learning platform as a tool to support the organisation, tutoring and learning of the contents. This will allow us to assess the effects that communicative and information ecologies have on learning processes in a networked society.
\end{abstract}

Keywords-Digital competences, digital inclusion, digital citizenship, learning platforms, blended learning, networked society.

\section{INTRODUCTION}

The pandemic has made us more digital, both in terms of daily connection time and in the diversity of facets of life that we base on technology: telecommuting, consumption, education, personal relationships, leisure and access to content [2] Digitalisation is strategic for all citizens, and critical digital competence should be universalised as a matter of urgency. However, both European citizenship and Spanish citizenship in particular are facing significant shortcomings in this field, which particularly affect the most vulnerable groups in our society, increasing the already existing gaps and putting at risk other groups that -without being considered as vulnerable- are now also at a disadvantage.

This explains why very relevant public policies have been activated to tackle this issue once again, which admittedly is not new, as actions -sometimes unconnected- have been developed over the last thirty years to incorporate the whole of the citizenry into what used to be called the "information society". In the current attempt, we hope that the initiatives will be more successful, thanks to factors such as the digital acceleration caused by the pandemic, the political awareness of the seriousness of digital inequality and the enormous economic resources that will be devoted to this issue.

With regard to the European Union, let us recall that the Next Generation recovery plan [3] considers digitalisation to be a key axis, and this has been transferred to the Plan España Puede [Spain Can Plan] [4] as one of its four strategic lines, giving rise to plans to complete the digitalisation of companies, the education system and public administrations. Specifically for mass training in digital skills, the European Union has approved the Digital Education Action Plan 2021-2027 [5] and Spain has approved the Plan nacional de competencias digitales 
[National Digital Skills Plan] [6] -endowed with 3,750 million euros.

In Spain, the Plan aims to influence the digital competence of a) the educational community at all levels, b) companies and the working population in both the public and private sectors, c) the promotion of digital specialists, and d) "citizens" in general, with an emphasis on groups at risk of digital exclusion and on the gender digital divide. With this last objective, there is a line of action focused on training in basic digital skills, endowed with some eight hundred million euros with which it is hoped to reach the estimated fifteen million Spaniards who do not have these skills, as explained in more detail in [7].

In justifying this Plan, it was noted that there are 15 million people in Spain who lack basic digital skills. In addition, there are almost 12 million citizens at risk of social exclusion [8]. The correlation between social exclusion and digital exclusion has been proven on numerous occasions, with the digital divide being a factor that increases the other factors of vulnerability of people [9] because the lack of access and competence limits or excludes people from knowledge, communication, relationships, work or the exercise of rights. And it is not only a question of equipment and connectivity, but also of digital or informational competence to make meaningful use and take advantage of its possibilities in a reflexive and intentional way, in accordance with personal or collective purposes [10]. The recent study by the COTEC Foundation [11] on digital skills and groups at risk of exclusion in Spain particularly highlights the lower level of education, lack of employment and advanced age as the three factors that most determine the digital skills gap. And we should not forget how problematic and excluding this lack of digital skills is for older people, for example in the field of health.

In this state of affairs, a group of third sector entities led by the CEPAIM Foundation and the University of Murcia, research groups from the Universities of Murcia, Complutense, Jaume I, Oberta de Catalunya, Rey Juan Carlos, and Salamanca together with companies such as Vodafone and Prodigioso Volcán, and representative entities such as the Spanish Federation of Municipalities and Provinces (FEMP) and FESABID (Spanish Federation of Archives, Libraries, Document \& Museum Associations), set out to design a project that will focus on solving the problem of digital exclusion through training and citizen participation in the framework of public libraries as a public service of proximity and trust. The aim hereby is to describe this project, called $e$ $I R I S$, with which the promoter group is seeking funding to enable its financing and development. Therefore, we will contextualise and describe the training proposal and the proposed teaching-learning model, which will be supported by a learning platform created specifically for the project implementation.

\section{INSTITUTIONAL AND CONCEPTUAL FRAMEWORK FOR BASIC DIGITAL SKILLS EDUCATION}

Training in basic digital skills for the groups that are furthest away from them for socio-educational, economic or generational reasons is not effortless. It is not easy to reach vulnerable groups by digital means if they are affected by a lack of access, connectivity or competence, which is precisely what we are trying to remedy. Moreover, the purposes that drive this training should be not only instrumental but also empowering, relevant and transformative of the conditions under which the target people may be in a vulnerable situation.

The designed proposal considers public libraries as the most appropriate public infrastructure for training activities, as nearby and accessible spaces in the municipalities that allow for integrated, contextualised and participatory work, based on the following reasons:

- The positive social perception of these institutions, whose professionals are recognised as trustworthy, information experts, with a vocation for public service, fair access, ideological neutrality and commitment to freedom of information as a right and as an agent in the democratic quality of public administrations.

- The relevance given by libraries to information and digital literacy as an element of social inclusion, which has increased during the pandemic [12].

- Their track record in educational services, literacy training and user training programmes shows public libraries as mediators of lifelong learning.

- The diversity of target groups -from the elderly to vulnerable groups- with specific and diverse needs makes libraries ideal because they are a permanent and easily accessible network, reaching even empty Spain (areas of Spain that have suffered from the so-called rural exodus and have been largely depopulated), and have been serving the main identified target groups for a long time, in conjunction with third sector entities dedicated to social action and social services [7].

As for the conceptual framework that defines what we mean by digital competence, what skills it includes and at what levels they can be mastered, it is necessary to adhere to the European Digital Competence Framework [1], as it maintains a broad and ambitious vision of digital competence, structured in five areas (information and data literacy, digital communication and collaboration, content creation, security and problem solving) defining twenty-one sub-competences and four levels of possible proficiency.

Logically, at the same time as the e-IRIS project considers libraries as the physical nearby infrastructure for carrying out the programme, a digital space for training is incorporated, through a learning platform that constitutes a fundamental digital support for training, so that both the learning mediators and the participants in the training courses designed -depending on their progressive autonomy and with the appropriate tutoring or support- learn digital competences from the practice of online learning. Also, in accordance with the critical and inclusive components of the DIGCOMP Framework, special attention is paid to the learning process: training in basic digital competences cannot be understood as one-off training of an instrumental nature, but should respond to the contextualised needs of each person, assuming the holistic perspective of CILIP's definition of information literacy [13]; that is, throughout 
life, enabling people to develop as citizens, facing the digital context with all the guarantees, without being left behind, and being able to use all the potential for their own individual and collective needs.

\section{E-IRIS PROJECT}

Therefore, the e-IRIS project is a citizen training and activation project whose primary aim is to train all citizens in basic digital skills, with special attention to the most vulnerable groups, from a social, community and citizenbuilding perspective which, with a strategy of complementarity, both in the fulfilment of objectives and in the learning process, takes into account the following principles:

- Lifelong learning in non-formal education contexts.

- Attention to the particular needs of groups at risk of digital exclusion.

- The generation of spaces for participation, mediation and awareness-raising.

- Opportunities for social innovation and artistic and cultural creation in the digital context.

- Social learning, based on learning communities, practice, problem solving and intercultural perspective.

- Learning from, for and with participation.

For its development, the project envisages the creation in libraries of "Digital Citizenship Spaces" (DCS; ECD in the original Spanish name, but in this paper we use the acronym in English) conceived as multifunctional rooms, with a flexible and modular configuration, allowing different modes of individual or collaborative work, enabling learning, guidance and creation, and above all overcoming the model that for years has prevailed in the Open Access Computer Classrooms in their various denominations: rows of computer stations lined up in front of a trainer's station and a projection screen or a digital whiteboard. They would be equipped with a high level of technological equipment and fibre and $5 \mathrm{G}$ connectivity, for carrying out training actions in individual, small and large group formats, as well as orientation activities, and group work and creation processes by the citizens participating in the programmes [14].

The training contents serve the double purpose of equipping citizens with the necessary life skills and encouraging their active participation in society. The aim is both to achieve digital skills that enable personal autonomy (which the DIGCOMP identifies as B1 level) and to promote social cohesion, with emphasis on the most vulnerable groups, through the following initial offer of workshops:

- On the use of information in the digital context.

- e-Inform: training in the critical, reflective and intentional use of information.

e-Thic: training in ethical aspects for the responsible use of ICT and basic digital competence in social and current affairs information, audiovisual and media literacy: disinformation and identification of fake news, responsible communication of content.
- e-Tiquette: training in netiquette and appropriate communication rules in different digital contexts, networks or platforms.

- e-Safe: training in the safe use of networks.

- e-Organise: training in personal information management, organisation of one's own digital content, as well as the conservation, access and use of personal electronic information in local environments or "the cloud".

- On the use of digital resources in life contexts.

- e-Health: digital training in health and healthy living, health and health information on the Internet and other sources, healthy lifestyle habits, nutrition and physical activity, personal and family health, parenthood...

- e-Economy: digital training in home economics, basic financial literacy, home accounting, consumer decisions, sources of information for the private economy and consumption, banking...

- e-Science: training in digital competence for scientific literacy; basic theory and practice of science, technology, engineering and mathematics; stimulation of STEM vocations.

- e-Learning: training in digital competence for learning, access to educational information, online learning tools, open educational resources...

- e-Family: training on digital tools for the education of children, digital habits in the family context, education and family digital leisure.

- e-LogOff: training in the prevention of digital dependence, network addiction and online time management.

- On the development and exercise of citizenship in the digital context.

- e-Transparency: training on the right to know and transparency; the right to information on political management and public administrations.

- e-Building: training for the joint development of activities, collaboration in the digital context and the development of cooperative citizen initiatives, including training in citizen entrepreneurial culture.

- e-Sustainability: training for sustainability and environmental literacy.

- e-Equal: training in equality and nondiscrimination.

- e-Gender: training in digital skills with a gender focus.

- On the use of digital resources for digitally excluded groups.

e-ICT: training in basic skills for the instrumental use of information and communication technologies and their most common devices.

e-Resources: digital training on the search for local resources (social, health, educational, cultural, leisure, etc.), electronic relations with agents and administration, etc. 
e-Housing: digital training in the search for and management of residential and housing alternatives, coexistence, neighbourhood associations, maintenance and conservation,...

e-Employment: training in basic digital competence for the working environment, labour or employment literacy (needs related to job search, labour relations, labour or trade union rights... Jobspecific training is not included here).

The implementation of these trainings would be done through itineraries according to a process of evaluation and self-assessment of the initial level of digital competence, which would define the actions to be carried out by each person in order to reach the target competence level.

The e-IRIS project also includes a training of trainers programme for library staff, for mediators in the tutoring processes both through the learning platform and in person, and for the training of digital cyber-volunteers and for agents of the social transformation process of the third sector involved in the Plan. The definition of training content will be based on a consultation -currently in the pilot phase- that will allow us to learn about the degree of mastery of the digital competence of local librarians, and which we hope will contribute to their necessary updating through the following programmes:

- e-Librarian: training of trainers in digital skills and dynamisation of the DCS.

- e-Solidarity: training for the implementation of digital cyber-volunteering activities in the DCS.

- e-Transform: training for agents of social transformation in the digital context.

e-IRIS proposes an integrative, inclusive and participatory learning methodology, based on collaboration, practice and the resolution of contextualised problems in everyday life situations, beyond the educational and work environment. Therefore, in the DCS there would be lines of action that will be complementary to the training itself, under this model:

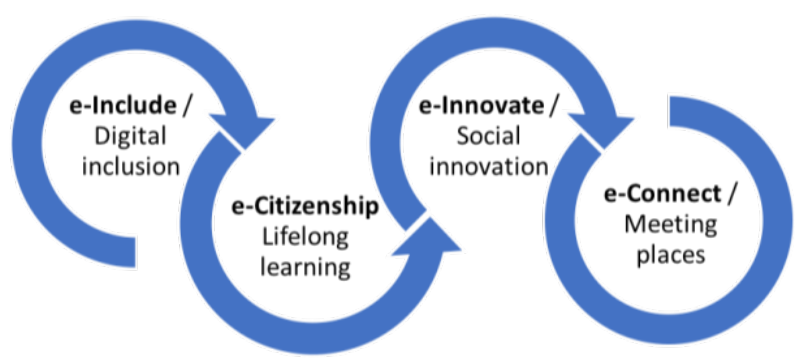

Figure 1. DCS model [14]

Together with the set of training activities described above, which we refer to as e-Citizenship in a global way, $e$ Include would be a set of individual guidance and care services for people at risk of digital exclusion and device loan services (e-Media, e-Guide, e-Share); e-Innovate, would consist of citizen laboratories for artistic creation and social and cultural innovation (e-Produce, e-Create, e-Lab,
$e$-Voice); and e-Connect, would propose meeting and social interaction spaces for the development of group activities such as debate forums, talks, breakfasts, reading workshops, storytelling, etc. aimed at fostering social inclusion and cohesion (e-Activate, e-Deactivate, e-Memory).

\section{THE E-IRIS LEARNING AND PROJECT MANAGEMENT PLATFORM}

The project includes the development of a technological platform for pedagogical support that will enable to carry out both the initial and final assessments of the participants, as well as the monitoring of the rest of the activity indicators of all the lines of action. e-IRIS will centralise its educational content on this learning platform, which will serve as a workspace for the mediators, who will act as literacy agents. At the same time, the platform will be an open knowledge portal for the programme's content.

The platform will take into account the technological and pedagogical conventions of similarly oriented educational portals, but also aims to achieve more ambitious objectives, given the dimensions of the project and its open and participatory nature. The aim is to create a portal in which the pedagogical mission is on an internal level, so that the real interface for citizens is a space for the consumption of informative and recreational content, where learning is assimilated in a natural way.

The principles on which the educational platform is developed focus on the objectives of the project, but adapting them to a space that is closer to people and intentionally away from a teaching environment. The platform will allow people to learn without the feeling of attending classes. Regardless of the technological developments, the basic elements that are being taken into account for the definition of the educational platform are described in the following table, structured in two main sections: a) inner layer or principles of the platform in relation to the objectives of the project, and b) outer layer or representation of the principles in the interfaces of the public environment.

TABLE 1. E-IRIS PLATFORM DEVELOPMENT PRINCIPLES. SOURCE: OWN ELABORATION

\begin{tabular}{|l|l|}
\hline Inner layer & Outer layer \\
\hline $\begin{array}{l}\text { Competences. Obtaining the digital competences } \\
\text { of the European framework and their adaptation } \\
\text { to the target groups of the project. Basis: } \\
\text { DigComp. }\end{array}$ & $\begin{array}{l}\text { Contents. Supply of learning resources based on } \\
\text { people's profiles and needs. Basis: Autonomous } \\
\text { selection. }\end{array}$ \\
\hline $\begin{array}{l}\text { Scalability. Sequential learning as competences } \\
\text { are acquired, based on a defined structure. Basis: } \\
\text { eIRIS lines. }\end{array}$ & $\begin{array}{l}\text { Knowledge. Gradual learning through educational } \\
\text { resources transformed into informative and } \\
\text { recreational content. Basis: Achievement badges. }\end{array}$ \\
\hline $\begin{array}{l}\text { Orientation. Grouping of contents by means of } \\
\text { training packages that enable comprehensive } \\
\text { training in related subjects. Basis: elRIS training. }\end{array}$ & $\begin{array}{l}\text { Itineraries. Relationship between contents of } \\
\text { similar interest to be selected according to } \\
\text { specific interests. Basis: Suggested routes. }\end{array}$ \\
\hline $\begin{array}{l}\text { Usability. Content structuring based on criteria of } \\
\text { user-friendliness and simplicity of use, avoiding a } \\
\text { curricular organisation. Basis: e-IRIS design. }\end{array}$ & $\begin{array}{l}\text { Appeal. Aesthetics, graphic image and } \\
\text { multimedia production of training contents that } \\
\text { help learning in a natural way. Basis: Learning } \\
\text { objects. }\end{array}$ \\
\hline $\begin{array}{l}\text { Openness. Development of the portal and its } \\
\text { contents using open standards that allow public } \\
\text { distribution. Basis: Open source. }\end{array}$ & $\begin{array}{l}\text { Community. Open use and re-use of content } \\
\text { through licences that facilitate the common good. } \\
\text { Basis: Open access. }\end{array}$ \\
\hline
\end{tabular}

\section{FINAL REFLECTIONS}

The implementation of this project will involve the acquisition of basic digital skills. e-IRIS is designed to be able to accompany people throughout their digital growth. The project takes a step forward from traditional approaches 
to digital literacy, which are very focused on the acquisition of functional skills, and aims to be the key to development towards the so-called digital fluency, that is, the ability to confidently and safely face unfamiliar situations in the digital sphere, also promoting a kind of resilience to change, assuming this literacy as part of lifelong learning.

Therefore, e-IRIS works with a double scope: that of inclusion and that of generalised digital citizen training. It is also an information and awareness-raising initiative on the importance of digitisation as an instrument of inclusion and will also serve to reinforce the redefining of libraries as spaces of nearby and digital citizenship.

e-IRIS is a digital literacy and inclusion project, but also a way to support the transformation of the Spanish public library network and strengthen its role as an element of social cohesion. In addition, the initiative seeks to open new debates on digital inequality and ways to fight against it.

If European funds can be used to make the Digital Citizenship Spaces and the e-IRIS project a reality, we will achieve synergies and benefits for the different regional library networks: updating their infrastructures, increasing services, and making efficient use of public resources to improve library systems that already exist but are in need of funding after the crisis.

The fact that digital education programmes are carried out in a space of citizenship such as libraries has added values, as those reiterated throughout our proposal: it favours exchanges, interculturality, social innovation, the culture of equality, the meeting of different people in a neighbourhood or community with their different circumstances and, as a result, inclusion and social cohesion. Furthermore, the use of libraries as educational spaces has the benefit of encouraging citizen participation, beyond merely instrumental training.

\section{REFERENCES}

[1] S. Carretero, Vuorikari, R. and Y. Punie, "The Digital Competence Framework for Citizens With eight proficiency levels and examples of use. Publications Office of the European Union". Luxembourg: Publications Office of the European Union, 2017, DOI: https://doi.org/10.2760/38842

[2] National Observatory of Technology and Society, "Competencias digitales de los internautas. Análisis de datos INE 2020. Madrid. https:/www.ontsi.es/sites/ontsi/files/2021-

05/competenciasdigitalesinternautas2020.pdf

[3] European Commission, "Proposal for a regulation of the European Parliament and of the Council establishing a Recovery and Resilience Facility. Luxemburgo, 2020, https://eur-lex.europa.eu/legalcontent/EN/TXT/PDF/?uri=CELEX:52020PC0408

[4] Government of Spain, "España Puede. Plan de recuperación, transformación $y$ resiliencia”, Madrid, 2020 https://www.lamoncloa.gob.es/presidente/actividades/Documents/202 0/07102020 PlanRecuperacion.pdf

[5] European Commission, "Digital Education action Plan 2021-2027: Resetting education and training for the digital age. Bruselas, 2020 https:/ec.europa.eu/education/sites/default/files/document-librarydocs/deap-communication-sept2020_en.pdf

[6] Government of Spain, "Plan nacional de competencias digitales", Madrid, 2021 https://portal.mineco.gob.es/RecursosNoticia/mineco/prensa/noticias/ 2021/210127_np_digital.pdf

[7] J. A. Gómez-Hernández and M.A. Vera-Baceta, "Las bibliotecas públicas españolas ante los fondos europeos de recuperación y el Plan nacional de competencias digitales", Anuario ThinkEPI, 2021, DOI: https://doi.org/10.3145/THINKEPI 2021.E15B01

[8] EAPN, "El estado de la pobreza. Seguimiento del indicador de pobreza y exclusión social en España. $10^{\circ}$ Informe 2020".Madrid, 2020 www.eapn.es

[9] E. Raya-Díez, "Exclusión social: indicadores para su estudio y aplicación para el trabajo social”, Revista Del Ministerio de Trabajo e Inmigración, (70), 155-172, 2007, http://www.empleo.gob.es/es/publica/pub_electronicas/destacadas/rev ista/numeros/70/Inf01.pdf

[10] J.A. Gómez-Hernández, M. Hernández-Pedreño and E. RomeroSánchez, "Social and digital empowerment of vulnerable library users of the Murcia Regional Library, Spain", Profesional de la información, 26(1), 20, 2017, https://doi.org/10.3145/epi.2017.ene.03

[11] L. Hernández and J. Maudos, "Competencias digitales y colectivos en riesgo de exclusión en España”, Madrid, 2021, $\mathrm{https}$ //cotec.es/proyecto/competencias-digitales/51a02688-a11f-4feeb047-41288ea0e0ac

[12] E. Romero-Sánchez, M. Hernández-Pedreño and J.A. GómezHernández, "Función social y digital de las bibliotecas públicas en España tras la crisis económica y sociosanitaria: perspectivas y retos" Profesional de La Información, 30(5), 2021 DOI: https://doi.org/10.3145/EPI.2021.SEP.10

[13] D. Sales, "Definición de alfabetización informacional de CILIP, 2018". Anales de Documentación, v. 23, n. 1, 2020, DOI: https://doi.org/10.6018/analesdoc.373811

[14] M.A. Vera-Baceta and J.A. Gómez-Hernández, "Espacios de ciudadanía digital en las bibliotecas públicas: una propuesta para su integración en el marco del Plan nacional de competencias digitales" $\begin{array}{lll}\text { Anuario } & \text { ThinkEPI, } 2021 \text { DOI: }\end{array}$ https://doi.org/10.3145/THINKEPI 2021.E15B02 